\title{
Potential of historical meteorological and hydrological data for the reconstruction of historical flood events - the example of the 1882 flood in southwest Germany
}

\author{
J. Seidel ${ }^{1}$, F. Imbery ${ }^{2}$, P. Dostal ${ }^{3}$, D. Sudhaus ${ }^{4}$, and K. Bürger ${ }^{5}$ \\ ${ }^{1}$ Institute of Hydraulic Engineering, Department of Hydrology and Geohydrology, Universität Stuttgart, Germany \\ ${ }^{2}$ Meteorological Institute, University of Freiburg, Germany \\ ${ }^{3}$ Department of Computer Science, Environmental Modelling Group, University of Mainz, Germany \\ ${ }^{4}$ Department of Physical Geography, University of Freiburg, Germany \\ ${ }^{5}$ DUC, Environmental Consulting Agency, Freiburg, Germany
}

Received: 31 October 2008 - Revised: 8 January 2009 - Accepted: 16 January 2009 - Published: 17 February 2009

\begin{abstract}
This paper presents a hydrometeorological reconstruction of the flood triggering meteorological situation and the simulation of discharges of the flood event of December 1882 in the Neckar catchment in Baden-Württemberg (southwest Germany). The course of the 1882 flood event in the Neckar catchment in southwest Germany and the weather conditions which led to this flood were reconstructed by evaluating the information from various historical sources. From these historical data, daily input data sets were derived for run-off modeling. For the determination of the precipitation pattern at the end of December 1882, the sparse historical data were modified by using a similar modern day precipitation pattern with a higher station density. The results of this run-off simulation are compared with contemporary historical data and also with 1-D hydraulic simulations using the HEC-RAS model.
\end{abstract}

\section{Introduction}

Historical floods are receiving increased attention in flood research and in applied flood protection (Glaser and Stangl, 2004; Thorndycraft et al., 2002; Benito et al., 2004). They can be taken into account for the improvement of long term data series and their statistical validation as well as for the analysis of return periods (e.g. Barriendos et al., 2003). After

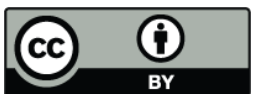

Correspondence to: J. Seidel (jochen.seidel@iws.uni-stuttgart.de) the Elbe flood of 2002, the German Federal Ministry of Education and Research (BMBF) founded the national research programme "Risk Management of Extreme Flood Events" (RIMAX) to avoid or limit the adverse impact of floods in Germany (Merz and Didszun, 2005). The research project Xfloods - "Analysis of Historical Floods for a Preventive Risk Management of Extreme Floods" - at the University of Freiburg was part of this initiative from 2005-2007, focusing on historical extreme floods in southwest Germany (Bürger et al., 2006). Information from historical documents has a great potential for the reconstruction of floods in the past and can be informative for contemporary flood risk management (Lobanova, 2002; Thorndycraft et al., 2002). In current research, there are different ways to analyse historical flood events for flood risk management. The method presented in this paper is the analysis of the flood triggering meteorological situation. Studies for historical flood events were presented for several regions in Europe (e.g. Bárdossy and Filiz, 2005; Jacobeit et al., 2003) but these usually focus on large-scale circulation patterns and their relation to flood events. Our approach uses information from historical data, such as meteorological and hydrological measurements to reconstruct past flood events and to understand their hydrometeorological causes. The use of documentary archives for the reconstruction of particular flood events or for flood chronologies has great potential and can be used to improve flood risk management or to assess the role of climatic variability on floods (Glaser and Stangl, 2004). The course of the 1882 flood event in the Neckar catchment in southwest Germany and the weather conditions which led to this flood

Published by Copernicus Publications on behalf of the European Geosciences Union. 


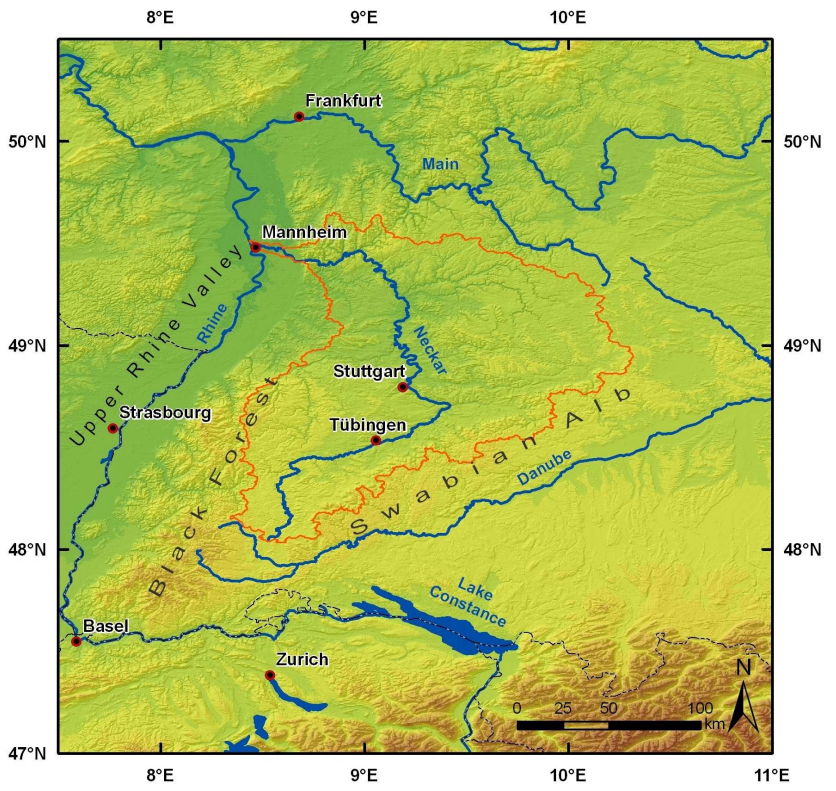

Fig. 1. Overview map of the study area. The orange line depicts the catchment of the Neckar River.

were reconstructed by using the information from various historical sources. Discharges in the Neckar catchment for this flood event were simulated with the water-balance model LARSIM (Large Area Run-off Simulation model) (Ludwig and Bremicker, 2006) and the 1-D model HEC-RAS (Hydrologic Engineering Center River Analysis System) (Hydrologic Engineering Center, 2005).

\section{Study area}

The study area for the discharge simulation of the flood event in December 1882 encompasses the Neckar catchment, which is the largest complete river basin within this area and in the Federal State of Baden-Württemberg (southwest Germany). The wider study area extends from $47^{\circ}$ to $50.5^{\circ} \mathrm{N}$ and $7.5^{\circ}$ to $11^{\circ} \mathrm{E}$ and includes large parts of southwest Germany, northern Switzerland, and the Alsace-Lorraine region in eastern France with the Vosges mountain range (Fig. 1). This region delimitates the area in which historical meteorological and hydrological data were collected. The Neckar River has a length of $367 \mathrm{~km}$ and rises in the eastern Black Forest mountain range. With a catchment size of $14000 \mathrm{~km}^{2}$ the Neckar River is the principal tributary to the Upper Rhine. In the lower course of the Neckar River between Heidelberg and Mannheim, the mean, minimum and mean flood discharges are $145 \mathrm{~m}^{3} \mathrm{~s}^{-1}, 42 \mathrm{~m}^{3} \mathrm{~s}^{-1}$ and $1150 \mathrm{~m}^{3} \mathrm{~s}^{-1}$ respectively (LfU, 2005). The elevation in the Neckar catchment ranges from $1020 \mathrm{~m}$ a.s.l. in the Black Forest to $78 \mathrm{~m}$ a.s.l. at Mannheim. The precipitation in the region is strongly modified by the local orography. The highest mean annual precipitation val- ues of up to $2000 \mathrm{~mm}$ occur in the Northern Black Forest. Towards the eastern part of the study site, the mean annual precipitation decreases to values of 800-1000 mm (Rapp and Schönwiese, 1996).

\section{Material}

\subsection{Historical meteorological data}

For the analysis of the 1882 flood event in southwest Germany, a variety of different data sets was consulted in order to obtain a clear picture of the events which occurred during the last quarter of 1882. Towards the end of the 19th century, regular meteorological measurements are available for all of Central Europe. These meteorological observations were regularly published by various national weather observation services, e.g. Meteorologische Beobachtungen in Deutschland (Seewarte Hamburg), Annalen der Schweizerischen Meteorologischen Zentralanstalt and monthly reports of the forest-meteorological stations in Alsace-Lorraine. For southwest Germany and the adjacent regions in northern Switzerland and eastern France, daily observations from 46 stations are available for the reconstruction of the meteorological conditions in 1882 . These data usually contain three daily measurements of the air pressure, air temperature, relative humidity, wind direction and strength, degree of cloudiness and precipitation. Additional information is supplied by weather symbols indicating the occurrence and duration of phenomena such as precipitation, fog, etc. Mean daily air temperatures $(\bar{T} a)$ are derived according to the formula

$\bar{T} a=\frac{1}{4}\left(T_{7}+T_{14}+2 T_{21}\right)$

where $T_{7}$ is the temperature reading at 7 a.m., $T_{14}$ is the reading at 2 p.m. and $T_{21}$ is the reading at 9 p.m ("Mannheim hours"). This method was common in Germany until 2001. A study by Siogas (1972) for Innsbruck (Austria) shows that the Mannheim hours tend to overestimate the $24 \mathrm{~h}$ average by a mean value of $0.2 \mathrm{~K}$. Furthermore, these deviations show a seasonal cycle with a minimum in late summer and a maximum in winter and spring. Since the mean daily air temperature is a subordinate parameter for the reconstruction of historical flood events, these systematic differences are negligible.

In addition to these data, daily precipitation amounts for various sites from 25 to 28 December 1882 are reported by Honsell and Tein (1891). Daily precipitation amounts for the year 1882 are also available for 26 stations in the Alsace-Lorraine region from MéteoFrance. All in all, the daily precipitation amounts during the flood event of December 1882 are available for 71 stations in southwest Germany and the adjacent areas in northern Switzerland and eastern France. Further descriptive information about the course of the weather and flood event were gathered from contemporary newspaper reports. 


\subsection{Large scale reconstructed meteorological data}

The atmospheric circulation patterns before and during the 1882 flood event were derived from the EMULATE data set (Ansell et al., 2006), which comprises daily SLP-Grids with a $5^{\circ} \times 5^{\circ}$ resolution for Europe and the North Atlantic. These data are supplemented by contemporary annual weather reports, e.g. issued by the former meteorological weather office of the Grand Duchy of Baden.

\subsection{Historical hydrological data}

Historical water gauge measurements for the 1882 flood event are available at over 30 sites in along the Upper Rhine and its tributaries (Honsell and Tein, 1891). In the Neckar catchment there were six gauging stations in operation in 1882, from which daily data on water stages are available. Furthermore, hydrological cross profiles with water stages of the 1882 flood at nine sites along the River Neckar are available from historical sources. These cross profiles are situated between Rottweil (river km 344) and Gemmrigheim (river $\mathrm{km} \mathrm{137).} \mathrm{The} \mathrm{historical} \mathrm{cross} \mathrm{profiles} \mathrm{were} \mathrm{used} \mathrm{to} \mathrm{model}$ flood discharges with the HEC-RAS model (Sudhaus et al., 2008). In the city of Tübingen, a historical cross profile of the gauging station as well as daily water stages are available. Hence it is possible to calculate daily discharges using the stage-discharge curve determined with HEC-RAS. The gauging station at Tübingen is also the reference station for comparing historical discharges from 1882 with the LARSIM simulations (see Sect. 5.4).

\section{Methods}

4.1 Run-off simulation with LARSIM and meteorological input parametrization

The discharges for the 1882 flood event are simulated with the water balance model LARSIM (Ludwig and Bremicker, 2006). This model was used because it is the operational flood forecasting model for the Federal State of BadenWürttemberg and respectively for the Neckar catchment. The LARSIM model is based on a $1 \mathrm{~km}$ grid and incorporates different meteorological parameters (e.g. air temperature, precipitation, air pressure, wind direction, wind velocity), as well as 16 land-use classes and current river profiles. Several studies (e.g. Bürger et al., 2006; Haag et al., 2005; Ott and Uhlenbrook, 2004; Bronstert et al., 2003) have shown that on large scales land use influences on discharge values during advective hydrometeorological extreme events are relatively small. Therefore, the historical land use from 1882 was not considered for the LARSIM simulation. Some hydrometeorological parameters such as air humidity were not considered either because of their minor influence on discharges during such an extreme event. For other parameters

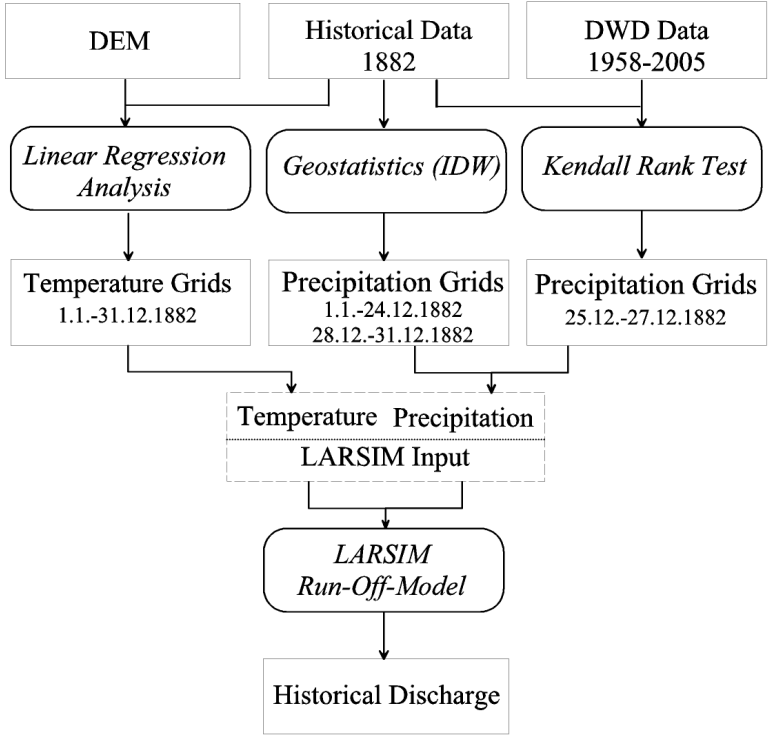

Fig. 2. Flowchart for obtaining meteorological input data for LARSIM using historical data.

like wind speed and sunshine duration there was no information available from the historical meteorological observations. Therefore, the LARSIM simulation for the 1882 flood event was carried out with the current parametrization and only the meteorological parameters temperature and precipitation were modified accordingly with the historical values from 1882. For the snow module in LARSIM, the threshold for air temperature below which precipitation falls as snow was set to $+1.5^{\circ} \mathrm{C}$ (daily mean value). The historical station network is less dense than the station density currently implemented in LARSIM. For the discharge simulations with the water balance model LARSIM it was therefore necessary to create daily temperature and precipitation grids for southwest Germany as input data for the rainfall run-off simulation. From these grids, the corresponding meteorological parameters (temperature, precipitation) were derived at locations of the current LARSIM stations (Fig. 2).

\subsubsection{Deriving areal temperature from historical data}

Daily temperature grids from historical meteorological observations were derived by establishing a linear regression between altitude and daily temperature means for each station during the year 1882 on the basis of 22 reference stations in the study area. Afterwards, the SRTM digital elevation model $(D E M)$ was multiplied in the form of

$T_{(\mathrm{x}, \mathrm{y}) \mathrm{i}}=a_{\mathrm{i}} D E M_{(\mathrm{x}, \mathrm{y})}+b_{\mathrm{i}}$

where $T_{(\mathrm{x}, \mathrm{y}) \mathrm{i}}$ is the temperature at the $D E M$ raster cell with $\mathrm{x}$ as latitude and $\mathrm{y}$ as longitude, $a_{\mathrm{i}}$ and $b_{\mathrm{i}}$ are the derived daily regression coefficients and $i$ is the corresponding day of the year 1882 (DOY). 


\begin{tabular}{|ll|r|r|r|}
\hline Location & & $25 \operatorname{Dec}\left(d_{1}\right)$ & $26 \operatorname{Dec}\left(d_{2}\right)$ & $27 \operatorname{Dec}\left(d_{3}\right)$ \\
\hline Freudenstadt & $\left(s_{1}\right)$ & $35.0 \mathrm{~mm}$ & $55.9 \mathrm{~mm}$ & $74.8 \mathrm{~mm}$ \\
Villingen & $\left(s_{2}\right)$ & $18.3 \mathrm{~mm}$ & $32.5 \mathrm{~mm}$ & $20.3 \mathrm{~mm}$ \\
Stuttgart & $\left(s_{3}\right)$ & $7.1 \mathrm{~mm}$ & $10.5 \mathrm{~mm}$ & $5.3 \mathrm{~mm}$ \\
Buchen & $\left(s_{4}\right)$ & $30.3 \mathrm{~mm}$ & $33.7 \mathrm{~mm}$ & $33.2 \mathrm{~mm}$ \\
Ansbach & $\left(s_{5}\right)$ & $0.2 \mathrm{~mm}$ & $21.4 \mathrm{~mm}$ & $16.1 \mathrm{~mm}$ \\
\hline
\end{tabular}

\begin{tabular}{|c|c|c|c|c|c|c|}
\hline & $s_{1}$ & $s_{2}$ & $s_{3}$ & $s_{4}$ & $s_{5}$ & \\
\hline$d_{1}$ & 35.0 & 18.3 & 7.1 & 30.3 & $0.2)$ & \\
\hline$d_{2}$ & 55.9 & 32.5 & 10.5 & 33.7 & 21.4 & historical data \\
\hline$d_{0}$ & 74.8 & 20.3 & 5.3 & 33.2 & $16.1)$ & \\
\hline
\end{tabular}
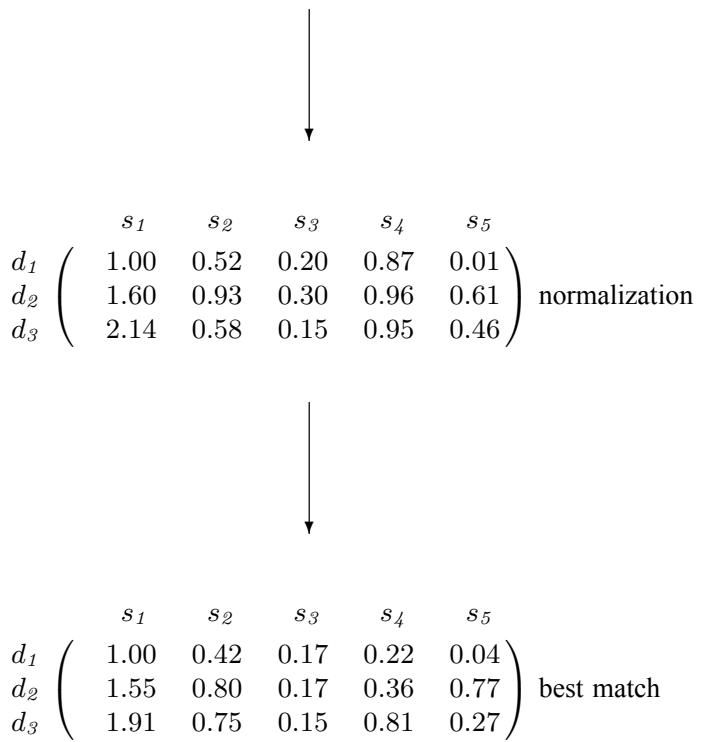

Fig. 3. Determination of a similar precipitation pattern with modern data using a Kendall test.

\subsubsection{Deriving areal precipitation from historical data}

For the detailed reconstruction of the precipitation in the Neckar catchment for 1882, geostatistical methods (Inverse Distance Weighting, Thiessen polygons, Co-Kriging with $D E M$ data as co-predictor) were used to obtain a quantitative precipitation distribution ( $1 \mathrm{~km}$ grid). The network of meteorological stations in southwest Germany and the adjacent areas was relatively dense in the 1880 s, but in the Neckar catchment area there is only data from eight stations available with daily precipitation and temperature readings. Nevertheless, the inverse distance weighting interpolation method (IDW) provides plausible results regarding the daily precipitation patterns for the period from 1 January to 24 December 1882. Due to snow fall, wind and only eight available precipita- tion measurements in the Neckar catchment, the data quality from 25 December 1882 onwards (during the flood event itself) is not sufficient in order to determine plausible precipitation patterns for the run-off simulation with LARSIM. Therefore, a comparable 3-day qualitative precipitation pattern for the period 25 to 27 December 1882 was detected in modern data set (Fig. 3) from the German Meteorological Service (Deutscher Wetterdienst). The aim was to establish a data set of precipitation patterns correlating to the historical data with a higher density of precipitation measurements. This was done as follows: In the first step, five representative stations (i.e. spatially well distributed over the study area) were defined: Freudenstadt, Villingen, Stuttgart, Buchen and Ansbach. A 5 by 3 matrix of precipitation data was created for the five stations $\left(s_{1}-s_{5}\right)$ and the corresponding three days (25-27 December $\left.1882\left(d_{1}-d_{3}\right)\right)$. These data were normalized by the value of Freudenstadt on 25 December $\left(s_{1}\right.$; $d_{1}$ ). In the same way, time series of recent precipitation data for these five observation sites were compiled for the period 1958-2005. Each matrix of the moving window was normalized as described above and compared with the normalized historical matrix with a Kendall rank correlation test (Abdi, 2007). With this nonparametric test, the degree of correlation of two samples, transferred to ranks, can be described. Kendall's $\tau$ is 1 if the agreement of the two rankings is perfect, $\tau=0$ means completely independence of the rankings.

\subsection{Hydraulic modeling of historical discharges}

For nine cross profiles with water stage information about the 1882 flood event, discharge calculations were carried out using the 1-D hydraulic model HEC-RAS 3.1.3 (Hydrologic Engineering Center, 2005). Previously, this model has been used successfully for palaeoflood studies (e.g. Benito et al., 2004; Thorndycraft et al., 2006). For the calculation of discharges, the selected cross profiles were digitized and the distances were converted from historical to SI-units. In a further step, the historical profiles were regionalized and the particular river slope was derived from the historical longitudinal profile of the Neckar River. A calibration of the model was not possible because the stage-discharge relations were not known for the historical cross profiles. Discharges were calculated as subcritical flow conditions (Sudhaus et al., 2008). The conditions during the flood event in the river channel (scour, fill, debris) as well as the adjacent flood plain are difficult to determine and thus have a factor of uncertainty. A study by Sudhaus et al. (2008) however has shown, that the best results are obtained by using standard values from HECRAS (river bed roughness 0.03 , floodplain roughness (high grass cover) 0.035 ). 


\section{Results}

5.1 Reconstructed atmospheric circulation pattern and weather conditions

In the year 1882, large parts of western Germany were hit by two large flood events. The first one, which is not part of this study, occurred at the end of November 1882 and affected mainly the lower course of the River Rhine. This flood event was caused by extraordinary high rainfall amounts in November 1882, peaking at a maximum between 23 and 26 November 1882. During the first half of December 1882, the weather was characterized by a strong high pressure area over Russia and eastern Europe, which led to calm weather conditions in the study area (Fig. 4a). This is also well documented by the meteorological observations in the region. In some parts of southwest Germany this led to a temperature inversion with sunshine and higher temperatures in the mountain ranges and fog and lower temperatures e.g. in the Upper Rhine Valley and the area around Lake Constance. From 21 December 1882 onwards, the circulation changed towards a meridional pattern, which brought cold air masses from the Northern Atlantic Ocean (Fig. 4b) into Central Europe. This led to a decrease in air temperature and heavy snowfall in most parts of the study area. According to meteorological data and descriptive data from the historical newspapers, the onset of the snowfall in southwest Germany was between 22 and 23 December. From 25 December 1882 onwards, the meridional circulation changed towards a zonal westerly pattern (Fig. 4c) which brought warmer air masses into Central Europe. This led to a rapid and strong temperature increase and long lasting rainfall, which caused the snow to melt that had fallen the days before. The combination of rainfall and snow melt led to devastating floods, especially in tributaries of the Rhine River. In some parts of the Neckar catchment, the water levels were only exceeded by the extreme flood event in 1824 (Bürger et al., 2006).

\subsection{Reconstructed precipitation and temperature patterns} for 1882

Using Kendall's rank coefficient test (see Sect. 4.1.2, Fig. 3), the best match for a similar precipitation pattern was found for the period between 29 to 31 January $1983(\tau=0.86)$. For this period, the linear regression between the historical data and the identified recent pattern resulted in $R^{2}=0.83$ and a regression coefficient of 2.16 .

To assess the verisimilitude of the reconstructed precipitation pattern, the normalized historical 3-day precipitation amounts (25-27 December 1882) among the five reference stations were compared with the recent long-term precipitation means (1961-1990) for the months December and January (Table 1). The historical 3-day precipitation sums are highly related to the corresponding normalized monthly means, showing that the historical event in 1882 as well as
Table 1. Table showing a comparison between the normalized 3day precipitation amount for the historical event from 25-27 December 1882 (A) and the normalized mean monthly precipitation amounts (1961-1990) for December (B) and January (C) for the five reference stations $\left(s_{1}-s_{5}\right)$.

\begin{tabular}{rccc}
\hline & $\begin{array}{c}\mathrm{A} \\
\text { Norm. 3-day } \\
\text { precipitation } \\
\text { December } \\
1882\end{array}$ & $\begin{array}{c}\text { B } \\
\text { precipitation } \\
\text { December }\end{array}$ & $\begin{array}{c}\mathrm{C} \\
\text { Normalized } \\
\text { precipitation } \\
\text { January }\end{array}$ \\
\hline Freudenstadt $\left(s_{1}\right)$ & 1 & & \\
Villingen $\left(s_{2}\right)$ & 0.43 & 0.45 & 1 \\
Stuttgart $\left(s_{3}\right)$ & 0.14 & 0.22 & 0.44 \\
Buchen $\left(s_{4}\right)$ & 0.59 & 0.44 & 0.11 \\
Ansbach $\left(s_{5}\right)$ & 0.23 & 0.19 & 0.24 \\
\hline
\end{tabular}

the modern pattern found with the Kendall test in January 1983 are representative events for winter precipitation in the study area.

For 1983 there were more than 400 precipitation data available in the study area. Precipitation grids were interpolated from these data and then multiplied by the regression coefficient of 2.16 in order to obtain the precipitation amounts for the situation from 25-27 December 1882. The pattern for 24 December is based on IDW interpolation. A correction of $+30 \%$ was applied for all historical precipitation data from 20 December 1882 onwards. This was necessary in order to account for measurement errors during snowfall and strong wind (Rapp and Schönwiese, 1996). Figure 5 shows the reconstructed temperature and precipitation for the study area from 24 to 27 December 1882. This period is characterised by a strong temperature increase from 25 to 26 December, where the temperatures rose up to $10 \mathrm{~K}$ within $24 \mathrm{~h}$. This strong temperature increase led to large scale snow melting even at higher altitudes of the Black Forest mountains. Information from contemporary meteorological and newspaper reports states, that the snow which had fallen from 22 December onwards, had completely melted by the evening of 26 December. From 24 to 27 December, the highest precipitation amounts occurred in the Black Forest and in the eastern and northern parts of the Neckar catchment. The daily precipitation amounts for 25 December ranged from $30 \mathrm{~mm}$ in the eastern parts of the Neckar catchment up to $50 \mathrm{~mm}$ in the Black Forest. Snowfall accounted for most of this precipitation. 26 December marked the transition from snowfall to rainfall. During this day the precipitation amounts summed up to $60 \mathrm{~mm}$ in the Black Forest. 27 December showed a similar precipitation pattern with local maxima in the Black Forest $(60 \mathrm{~mm})$ and the northeastern parts of the Neckar catchment $(40 \mathrm{~mm})$. The total precipitation from 25 to 27 December 1882 summed up to $180 \mathrm{~mm}$ in the Black Forest. During these three days, the central parts of the Neckar catchment received relatively little precipitation since this area is situated 
a)

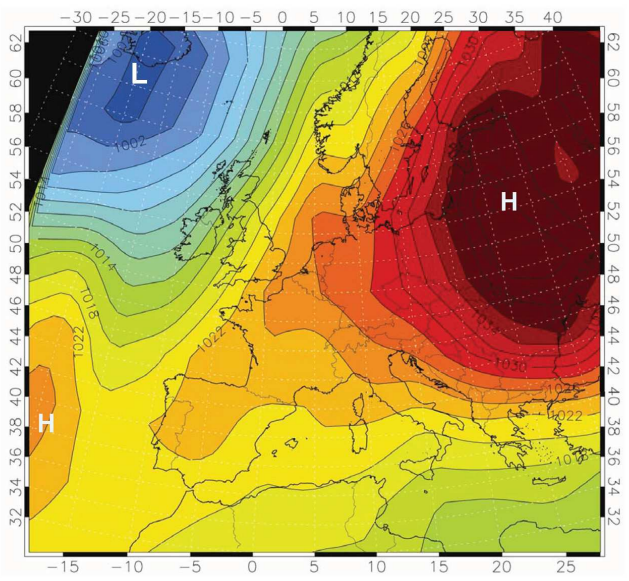

C)

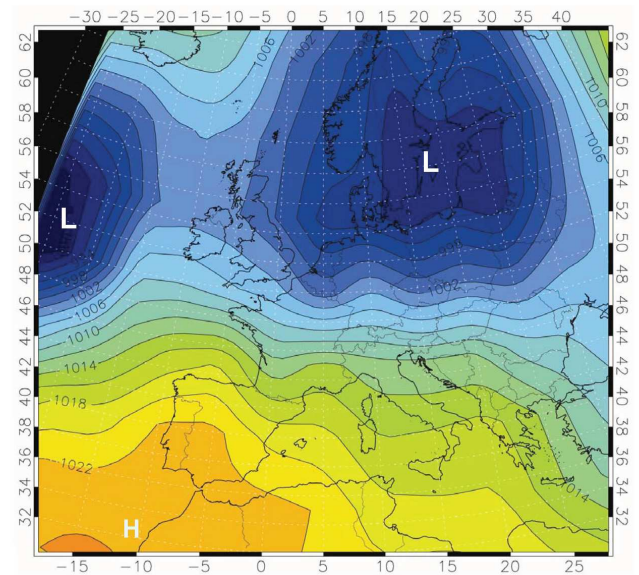

b)
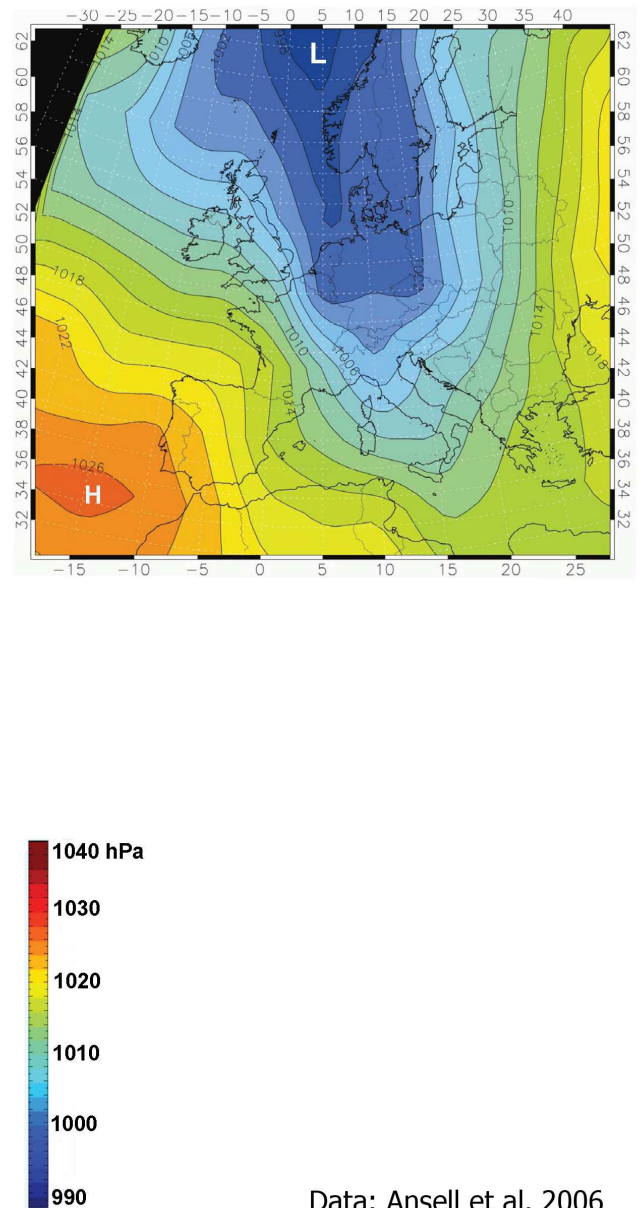

Data: Ansell et al. 2006

Fig. 4. Mean sea level pressure over Central Europe on (a) December 20, (b) December 23 and (c) December 261882.

on the leeward side of the Black Forest and thus in the rain shadow during westerly circulation patterns. The combination of snow melt and the strong precipitation led to this extreme flood at the end of December 1882.

\subsection{Water gauges and discharges}

Figure 6 shows water stage hydrographs at five sites along the Neckar River during the flood event. The graph was compiled with the historical data from Honsell and Tein (1891). All five sites show a relatively sharp increase in the water levels with approximately 1.5 days from the normal level to the flood peak. The water stage hydrographs of the Black Forest rivers tributary to the Rhine show similar characteristics. For the 1882 flood, contemporary discharge values were recorded by the water authorities of the Kingdom of Württemberg (Königliches Ministerium des Innern, 1896) and the Grand Duchy of Baden (Centralbureau für Meteorologie und Hydrographie, 1893). Following these reports, the water level in Heidelberg would correspond to a discharge of about $3000 \mathrm{~m}^{3} \mathrm{~s}^{-1}$, which is slightly higher than the HQ 100 (LfU, 2005).

\subsection{Discharge simulation with LARSIM}

Discharges resulting from the LARSIM simulation for Tübingen using the historical data from 1882 are shown in Fig. 7. This figure also includes the discharges from the gauging station which were converted from the water stages using the stage-discharge relation derived from the historical cross profile (see Sect. 4.2). Furthermore, the green line shows the mean discharge of $25 \mathrm{~m}^{3} \mathrm{~s}^{-1}$ at Tübingen for the period 1980-2003 (LfU, 2005). The graph shows a good correspondence between the discharges from the historical data and the LARSIM simulation, especially from January to June 1882. The first half of the year 1882 was characterised by low water flow due to large-scale low snowfall during the winter 1881/1882 and low precipitation in spring 1882 . 


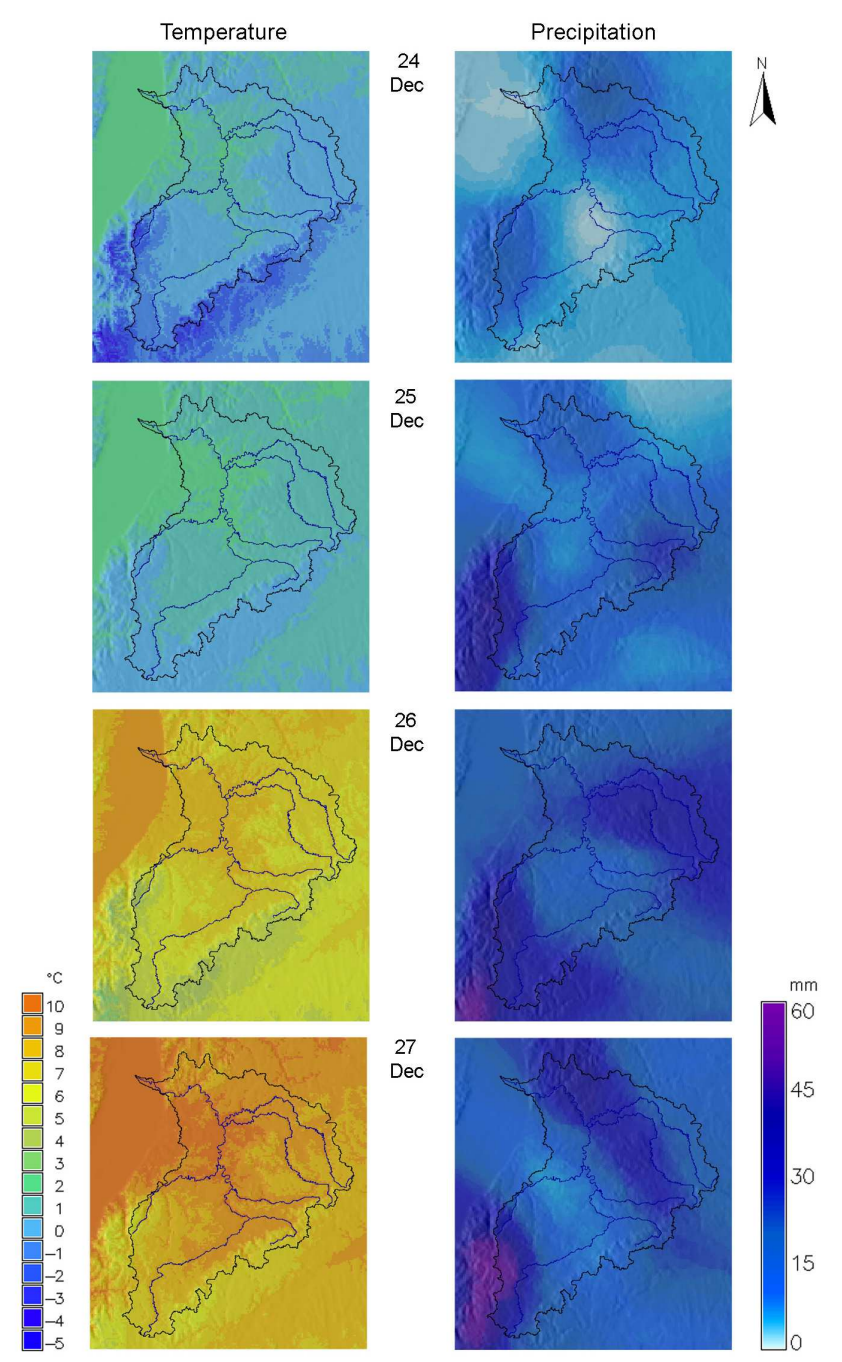

Fig. 5. Reconstructed temperature and precipitation in the Neckar catchment before and during the flood event from 24 to 27 December 1882 .

For the second half of the year, especially from September 1882 onwards, the discharge hydrograph shows increased run-offs clearly above the modern mean reference. The discharge peak for the flood event at the end of December 1882 (DOY 360) was correctly reproduced by the LARSIM simulation. This was accomplished by employing a precipitation correction for snowfall (cf. 5.2) and by using the more precise and higher resoluted precipitation pattern from 25 to 27 December 1882, which was derived with the modernanalogue method (cf. 4.2).

\subsection{Hydraulic discharge simulations in the Neckar catchment}

Figure 8 shows the results of the discharge calculations using HEC-RAS for the 1882 flood in comparison with the his-

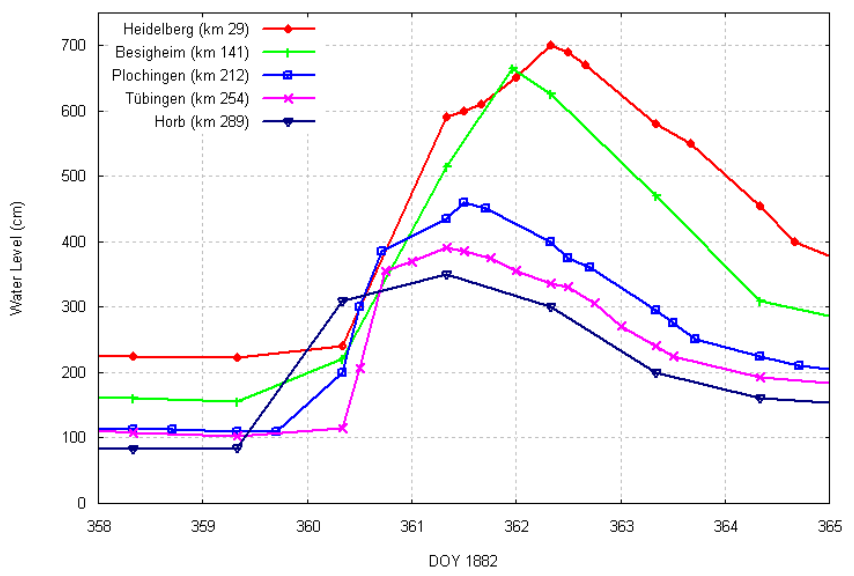

Fig. 6. Water stage hydrographs during the 1882 flood along the Neckar River at Horb, Tübingen, Plochingen, Besigheim and Heidelberg.

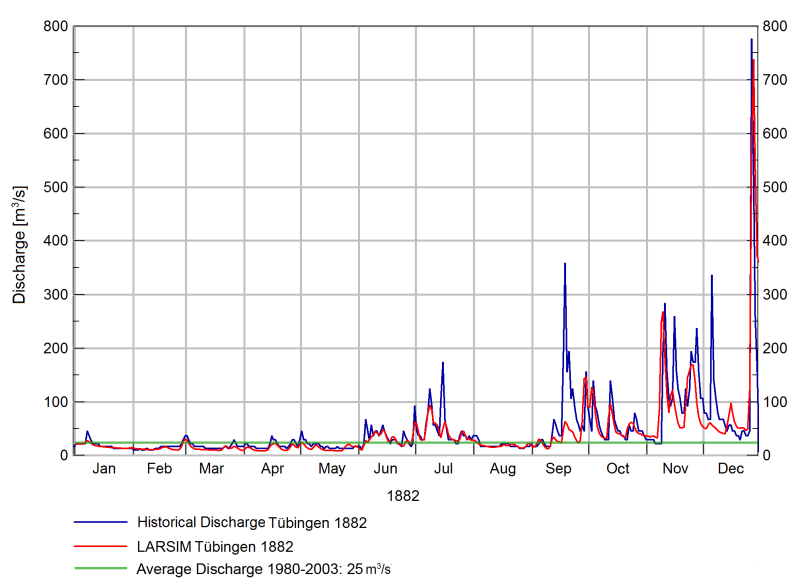

Fig. 7. Simulated discharges at the gauging station in Tübingen for 1882 .

torical calculations. The magenta triangles show the calculated discharges at nine cross profiles with HEC-RAS using the water level with standard roughness parameters and the olive triangles depict the discharges calculated using the energy line with standard roughness parameters (Sudhaus et al., 2008). Additionally, the results from the LARSIM simulation (see above), the discharges of the current HQ 100 (LfU, 2005) and the contemporary discharges calculations by the local water authorities from 1896 (Königliches Ministerium des Innern, 1896) are shown as lines. Except for the profiles in the upper course of the Neckar, where the flow area is relatively small, the discharges derived with HEC-RAS using the energy line and water surface with standard roughness values correspond well with the discharges from the administrative reports and the LARSIM simulations. 


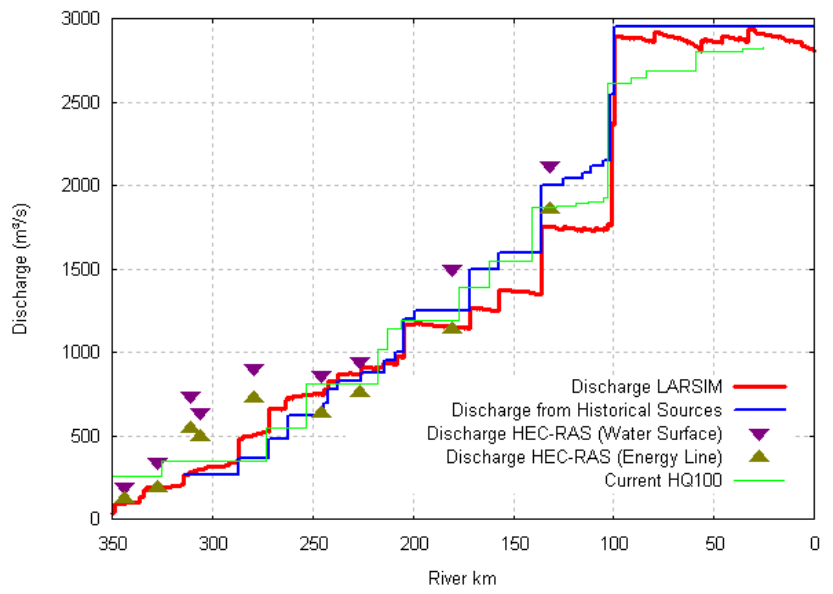

Fig. 8. Discharges for the Neckar during the flood of December 1882 from the LARSIM simulation, the HEC-RAS simulations, the historical administrative documents (Königliches Ministerium des Innern, 1896) and the current HQ 100 (LfU, 2005).

\section{Discussion}

The results from this study can be viewed and discussed from two different angles: punctual run-off data during the whole year of 1882 at the gauge in Tübingen and peak flood discharges along the channel of the Neckar River during the flood event at the end of December 1882. The gauging station at Tübingen has a catchment area of approximately $2000 \mathrm{~km}^{2}$ and covers large parts of the upper Neckar basin. The data derived from historical sources and run-off simulation can thus be regarded as representative for the upper Neckar catchment region. Unfortunately, no historical data with cross profiles and daily water stage measurements are available from sites further downstream, so there was no possibility to compare the results from Tübingen with other river sections of the Neckar. The comparison of the discharges from hydraulic simulations with the results from LARSIM (Fig. 7) show a high correlation, especially during the first half of the year 1882, where the hydrological situation was marked by low discharges. The smaller peak discharges in the second half of the year 1882 are also reproduced, although the discharges are generally underestimated in the LARSIM simulation using only the historical data (e.g. 16 July (DOY 197), 18 September (DOY 291) and 5 December 1882 (DOY 339)). This might be due to the rainfall characteristics in combination with the low density of meteorological observations. Local (convective) precipitation events which may have caused the discharge peaks are not properly captured by the surrounding rainfall gauges. Another reason for the underestimation of flood peaks is the temporal resolution of the LARSIM simulation (daily steps), which leads to certain limitations in the representation of rainfall intensities as well as the resulting run-off character- istics. This is also the case for the flood event at the end of December 1882, where a preliminary simulation of peak discharge at the gauging station in Tübingen was too low using the uncorrected historical data with the LARSIM model. A plausible run-off simulation of the 1882 flood was only possible after the adjustment of the precipitation data with the method presented in this study. This shows the necessity to resort to modern-day spatially high resolution data and comparable precipitation patterns in order to overcome the drawbacks of the historical meteorological data. The peak flood discharge simulation along the river channel of the Neckar River shows that the discharges derived from different independent sources correspond well, apart from three cross profiles in the upper Neckar section, where the hydraulic simulations produced outliers (Sudhaus et al., 2008). The historical discharge calculations from 1896 (which are based upon the river morphology at that time) as well as the LARSIM simulation using historical meteorological data and the current river morphology, yield discharges which correspond to a HQ 100. This leads to the conclusion that the hydrometeorological conditions of the flood of 1882 would also lead to a HQ 100 nowadays and that the run-off characteristic of a HQ 100 has not substantially changed since 1882, when using data with a daily temporal resolution.

\section{Conclusions}

The results presented in this paper show the potential of historical data for the reconstruction of flood events. A detailed analysis of flood events is generally possible if certain historical meteorological and hydrological data are available. In case of the 1882 flood event in the Neckar catchment, the combination of different datasets and methods conveys a comprehensive understanding of the processes leading to extreme flood events, including hydrometeorological and hydraulical aspects. Limitations of such historical flood reconstructions can occur when no or few reliable historical data are available in sufficient temporal and spatial resolution. This circumstance may affect the accuracy of precipitation intensity and the concourse of flood waves from tributaries and the main river. In order to answer this question further research is necessary, e.g. a sensitivity analysis for a river catchment using modern data with different temporal resolution. The importance of analysing historical floods is that they can be used to demonstrate the consequences of such extreme events and thus the knowledge can be incorporated into management. By combining historical precipitation and flood data with contemporary river channel morphology, current hazards and impacts can be predicted. This will lead to a better understanding of flood processes, as well as their characteristics. 
Acknowledgements. The authors would like to thank the BMBF (German Federal Ministry of Education and Research) and the Federal State Ministry of Science, Research and Arts in BadenWürttemberg for funding this research work.

Edited by: M.-C. Llasat

Reviewed by: D. Camuffo and one anonymous referee

\section{References}

Abdi, H.: Kendall rank correlation, in: Encyclopedia of Measurement and Statistics, edited by: Salkind, N. J., Sage, Thousand Oaks, USA, 2007.

Ansell, T. J., Jones, P. D., Allan, R. J., Lister, D., Parker, D. E., Brunet, M., Moberg, A., Jacobeit, J., Brohan, P., Rayner, N. A., Aguilar, E., Alexandersson, H., Barriendos, M., Brandsma, T., Cox, N. J., Della-Marta, P. M., Drebs, A., Founda, D., Gerstengarbe, F., Hickey, K., Jónsson, T., Luterbacher, J., Nordli, $\varnothing$. ., Oesterle, H., Petrakis, M., Philipp, A., Rodwell, M. J., Saladie, O., Sigro, J., Slonosky, V., Srnec, L., Swail, V., GarcíaSuárez, A. M., Tuomenvirta, H., Wang, X., Wanner, H., Werner, P., Wheeler, D., and Xoplaki, E.: Daily Mean Sea Level Pressure Reconstructions for the European North Atlantic Region for the Period 1850-2003, J. Climate, 19, 2717-2742, doi:10.1175/JCLI3775.1, 2006.

Bárdossy, A. and Filiz, F.: Identification of flood producing atmospheric circulation patterns, J. Hydrol., 313, 48-57, 2005.

Barriendos, M., Coeur, D., Lang, M., Llasat, M. C., Naulet, R., Lemaitre, F., and Barrera, A.: Stationarity analysis of historical flood series in France and Spain (14th-20th centuries), Nat. Hazards Earth Syst. Sci., 3, 583-592, 2003,

http://www.nat-hazards-earth-syst-sci.net/3/583/2003/.

Benito, G., Lang, M., Barriendos, M., Llasat, M. C., Francés, F., Ouarda, T., Thorndycraft, V. R., Enzel, Y., Bárdossy, A., Coeur, D., and Bobée, B.: Use of Systematic, Palaeoflood and Historical Data for the Improvement of Flood Risk Estimation, Review of Scientific Methods, Natural Hazards, 31, 623-643, 2004.

Bronstert, A., Niehoff, D., and Fritsch, U.: Auswirkungen von Landnutzungsänderungen auf die Hochwasserentstehung, Petermanns Geographische Mitteilungen, 147(6), 24-33, 2003.

Bürger, K., Dostal, P., Seidel, J., Imbery, F., Barriendos, M., Mayer, H., and Glaser, R.: Hydrometeorological reconstruction of the 1824 flood event in the Neckar River basin (southwest Germany), Hydrological Sciences Journal, 51, 864-877, doi:10.1623/hysj.51.5.864, 2006.

Centralbureau für Meteorologie und Hydrographie: Die Wassermengen der fliessenden Gewässer im Großherzogthum Baden, Beiträge zur Hydrographie des Großherzogthums Baden 8. Heft, Berlin, Germany, 1893.

Haag, I., Gerlinger, K., and Kolokotronis, V.: Auswirkungen von Windwurfschäden auf Hochwasserabflüsse am Beispiel des EnzNagold-Gebiets, Wasserwirtschaft, 10, 8-14, 2005.

Glaser, R. and Stangl, H.: Climate and floods in Central Europe since AD 1000: data, methods, results and consequences, Surv. Geophys., 25(5/6), 485-510, 2004.

Honsell, M. and Tein, M.: Auftreten und Verlauf der Hochwasser von 1824, 1845, 1852, 1876 und 1882-83, in: Centralbureau für Meteorologie und Hydrographie im Grossherzogthum Baden (ed.): Ergebnisse der Untersuchung der Hochwasserverhältnisse im deutschen Rheingebiet. Auf Veranlassung der Reichskommission zur Untersuchung der Stromverhältnisse des Rheins und seiner wichtigsten Nebenflüsse und auf Grund der von den Wasserbaubehörden der Rheingebietsstaaten gelieferten Aufzeichnungen, 2. Heft, Ernst, Berlin, Germany 1891.

Hydrologic Engineering Center: Hydrologic Engineering Centers River Analysis System (HEC-RAS), http://www.hec.usace.army. mil/software/hec-ras/hecras-hecras.html, 2005.

Jacobeit, J., Glaser, R., Luterbacher, J., and Wanner, H.: Links between flood events in Central Europe since AD 1500 and the large-scale atmospheric circulation modes, Geophys. Res. Lett., 30(4), 1172, doi:10.1029/2002GL016433, 2003.

Königliches Ministerium des Innern: Verwaltungsbericht der Königlichen Ministerialabteilung für den Strassen- und Wasserbau für die Rechnungsjahre vom 1. Februar 1893/94 und 1894/95, Stuttgart, Germany, 1896.

Landesanstalt für Umweltschutz (LfU): Abflusskennwerte in Baden-Württemberg, Karlsruhe, Germany, 2005.

Lobanova, M.: Application of past information for reducing flood risk (the case of Lensk city), in: Palaeofloods, Historical Data and Climatic Variability: Applications in Flood Risk Assessment, edited by: Thorndycraft, V. R.,Benito, G. Â., Barriendos, M., and Llasat, M. C., 231-236. CSIC, Madrid, Spain, 2002.

Ludwig, K. and Bremicker, M.: The Water Balance Model LARSIM - Design, Content and Applications, Freiburger Schriften zur Hydrologie 22, Freiburg, Germany, 2006.

Merz, B. and Didszun, J.: Risikomanagement extremer Hochwasserereignisse, Umweltwissenschaften und SchadstoffForschung, Z. für Umweltchemie und Ökotoxikologie, 17(4), 27-29, 2005.

Ott, B. and Uhlenbrook, S.: Quantifying the impact of land-use changes at the event and seasonal time scale using a processoriented catchment model, Hydrol. Earth Syst. Sci., 8, 62-78, 2004, http://www.hydrol-earth-syst-sci.net/8/62/2004/.

Rapp, J. and Schönwiese, C.-D.: Niederschlag- und Temperaturtrends in Baden-Württemberg 1955-1994 und 1895-1994, in: Wasser - Die elementare Ressource: Leitlinien einer nachhaltigen Nutzung, edited by: Lehn, H., Steiner, M., and Mohr, H., Springer, Berlin, Heidelberg, Germany, 113-170, 1996.

Siogas, L.: Vergleich von Temperaturmittelbildungen mit dem wahren Mittel für das Observatorium Innsbruck-Universitat, Wetter und Leben, 24, 17-22, 1972.

Sudhaus, D., Seidel, J., Brger, K., Dostal, P., Imbery, F., Mayer, H., Glaser, R., and Konold, W.: Discharges of past flood events based on historical river profiles, Hydrol. Earth Syst. Sci., 12, 1201-1209, 2008, http://www.hydrol-earth-syst-sci.net/12/1201/2008/.

Thorndycraft, V. R., Benito, G., Llasat, M. C., and Barriendos, M.: Palaeofloods, historical data and climatic variability: applications in flood risk assessment, in: Palaeofloods, Historical Data and Climatic Variability: Applications in Flood Risk Assessment, edited by: Thorndycraft, V. R., Benito, G., Barriendos, M., and Llasat, M. C., CSIC, Madrid, Spain, 3-9, 2002.

Thorndycraft, V. R., Barriendos, M., Benito, G., Rico, M., and Casas, A.: The catastrophic floods of AD 1617 in Catalonia (northeast Spain) and their climatic context, Hydrological Sciences Journal, 51, 899-912, 2006. 